\title{
Composite friend sisal / polyester treated in surface
}

\author{
J. K. D. Santos', R. A. D. Cunha', R. C. T. S. Felipe', R. N. B. Felipe', G. G. Medeiros'
}

${ }^{1}$ Núcleo de Pesquisa em Processamento de Petróleo e Gás Natural-Instituto Federal do Rio Grande do Norte jayna.dionisio@gmail.com - ricardoalexc@gmail.com - renata.felipe@ifrn.edu.br Raimundo.felipe@ifrn.edu.br-gilson.medeiros@ifrn.edu.br

Artigo submetido e em agosto/2011 e aceito em setembro/2011

\section{ABSTRACT}

The use of composites in manufacturing equipment and products is taking a very important space in the industry in general. Moreover these materials have unique characteristics when analyzed separately from constituents who are part of them. However it is know that cares must be taken in their manufacture, as the use of appropriate process and the composition of each element, in addition to adherence fiber / matrix, which is a major factor in obtaining of the final mechanical strength of the product. One should also take into account whether the composites are environmentally friendly. For this reason, in this work, a composite partially ecological was made, using as reinforcement, a sisal woven and, as matrix, the polyester resin. Seeking to improve the adherence fiber / matrix, a treatment in sisal woven was performed with aqueous solution of sodium hydroxide $(\mathrm{NaOH})$ at a concentration of $3 \%$. The composite subjected to this treatment presented, in bending test, a better mechanical performance, with an increase of $27 \%$ in the flexion strength and of $54 \%$ in maximum strain, but there was a reduction of about $15 \%$ in its flexural modulus.

KEY-WORDS: Composite, Sisal/polyester, Treatment, Bending 


\section{Composite friend sisal / polyester treated in surface}

\section{INTRODUCTION}

According Gay (1991), a composite is formed by different materials, is homogeneous when examined macroscopically and, moreover, may have long or short fibers, which are used in a phase of the material that is called reinforcement. Another phase of the composite is the matrix, which has an agglutinant function and causes the reinforcement to work in an integrated manner, supporting the mechanical stress (Pardini et al., 2006).

Several recent technological achievements, particularly those related to relevant applications in areas such as aeronautic, aerospace, petrochemical, shipbuilding, bioengineering, automotive, construction, and sporting goods, among others, became possible only after the advent of structural composites (Levy, 2006).

In the quest for sustainability, several researches and works in the composites area have been made to ensure environmental preservation and provide a better standard of living to the society. Among the researches in this area, those that seeking the application of natural resources in the preparation of materials are growing, and we could highlight the use of natural fibers of vegetable origin, due to the enormous variety of possible species to be surveyed. Several vegetable fibers are produced in virtually every country and they are usually identified as lignocellulosic materials. Some fibers occur spontaneously in nature, others are grown as agricultural activity and still others are wastes generated mainly by agroindustry (Silva et al., 2009).

However, according to Sydenstricker et al. (2003), many factors such as weather, age, soil type, extraction method, etc., can seriously affect the structure of plant fibers, their chemical composition and physical properties. As states, natural fibers (ligno-cellulosic) are lightweight and nontoxic, may have high elastic modulus and specific strength, cost about ten times less than the glass fiber and, unlike this inorganic fiber, cause less damage by abrasion to equipment and molds (Angrizani, 2006).

Among the various natural fibers, one make salient, in the manufacture of composite materials, the use of sisal, jute, hemp, ramie, palm, pineapple, sugar cane bagasse, wood fibers, coconut fibers, etc., which exhibit good mechanical properties as tensile, impact and others in various polymer matrices, especially the thermosetting ones (Mochnacz et al., 2002).

The versatility of sisal fibers, which adapt to different forming processes of composites such as filament winding, lamination, resin transfer molding, extrusion, injection, etc., gives to these fibers strategical importance in the development of new composites. Among other advantages of sisal, one can mention the facility of characteristic surface modification of vegetable fibers, their abundance in Brazil and easiness of cultivation. The hollow helical microstructure of the sisal is responsible for a failure mechanism distinct from other vegetable fibers, and the sisal reinforced composites show a work of fracture similar to the composites of ultra high molecular weight polyethylene (UHMWPE) reinforced by fiber glass (Amico, 2004). 
The waxy particles present on the surface of the fiber, minimize the adherence fiber / matrix, causing also a reduction in some mechanical properties of the composite, as proposed by Jang et al. (1994), who stated that an increase or a decrease of the properties of the fiber reinforced composites depends on the fiber microstructure and the properties of fiber / matrix interface. Below in Figure 1 can be seen the distribution of the percentage of a natural fiber microstructure untreated of sisal.

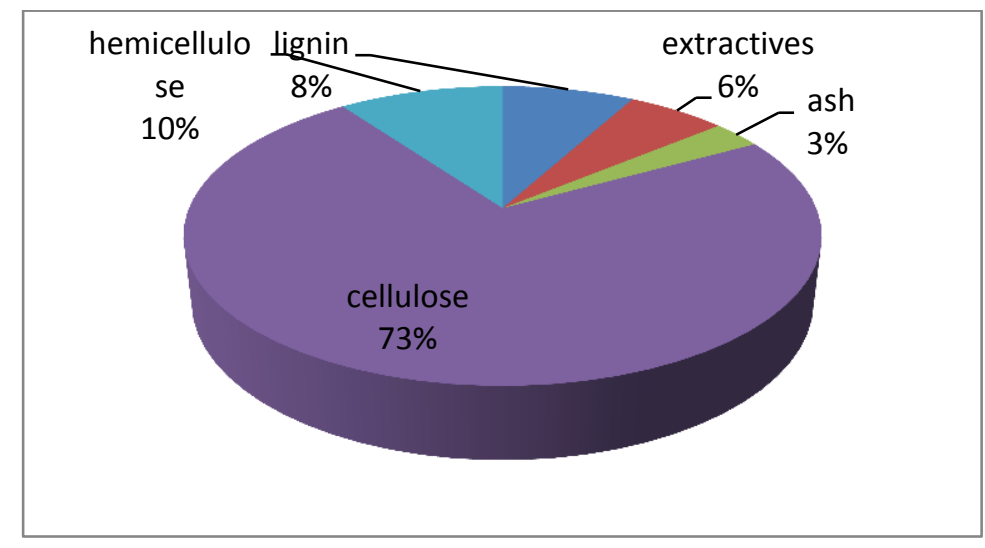

Figure 1: Chemical composition of untreated sisal fiber. Source: Amico, 2004.

As a result, the lack of good interfacial adhesion and the poor resistance to moisture absorption make it, sometimes, less attractive the use of composites reinforced with natural fibers. Different approaches such as chemical or physical modifications of the fiber, matrix or both components have been made to alter the adhesive properties of the fiber / matrix interface in composites reinforced with natural fibers. Studies about chemical treatments effect on the surface of many different natural fibers with sodium hydroxide, silanes, potassium permanganate, acetylation, $\mathrm{N}$-isopropylacrylamide, among others, in many different natural fibers, have better and better results in order to optimize the mechanical properties of composites due to better packing of cellulose chains after the dissolution of lignin, which is a cementing material. Other physical methods also performed on the fiber surface, such as corona treatment, plasma treatment and thermal treatment, have been studied, with positive changes in most cases (Sreekumar, 2009). In general, the treatments at vegetable fibers can significantly improve the adhesion at the interface allowing the penetration of resin into the reinforcement, thus contributing to better grip fiber / matrix (Rong et al 2001).

In this context, this study aims to obtain a composite consisting of orthophtalic polyester matrix reinforced with oxford basket sisal woven of plan type through the manual lamination manufacturing process, and check the influence on the density and mechanical properties (three point bending test) when reinforcement is chemically treated with sodium hydroxide $(\mathrm{NaOH})$ at a concentration of $3 \%$. 


\section{MATERIALS AND METHODS}

\section{Materials}

\section{Matrix and Reinforcement}

Composite plates were made with matrix of resin unsaturated orthophtalic polyester preaccelerated, manufactured by Novocol, with a density between 1.10 and $1.15 \mathrm{~g} / \mathrm{cm}^{3}$ and a Brookfield viscosity, at $25^{\circ} \mathrm{C}$, between 260 and 300cP. The catalyst for the cure of resin was methyl ethyl ketone (MEKP), manufactured by Akzo Nobel. The sisal fibers used for the manufacture of tissues were produced in the city of João Câmara, RN, having a medium diameter of $0.125 \pm 0.028 \mathrm{~mm}$, resulting in the weights of $43.0348 \mathrm{~g} / \mathrm{m}^{2}$ for the untreated tissue and $430878 \mathrm{~g} / \mathrm{m}^{2}$ for the tissue treated with sodium hydroxide.

\section{Equipments}

The equipments used for this work were: Universal testing machine (Pavitest/CONTENCO); Electronic analytical balance, model FA2104N (BIOPRECISA) and Micrometer, resolution of $0.001 \mathrm{~mm}$ (Mitutoyo).

\section{Solution for the Treatment}

It was used a sodium hydroxide solution of $3 \%$ for the treatment of sisal fibers.

\section{Methods}

\section{Manufacture of tissues}

The tissues were manufactured on a handloom with dimensions of $300 \times 300 \mathrm{~mm}$, as shown Fig.2 (a) using sisal strands with 20 wires each, arranged in the warp and interlaced by the weft in the manner to obtain the tissues of Basket Oxford type with 2x1 configuration, see Fig. 2 (b).
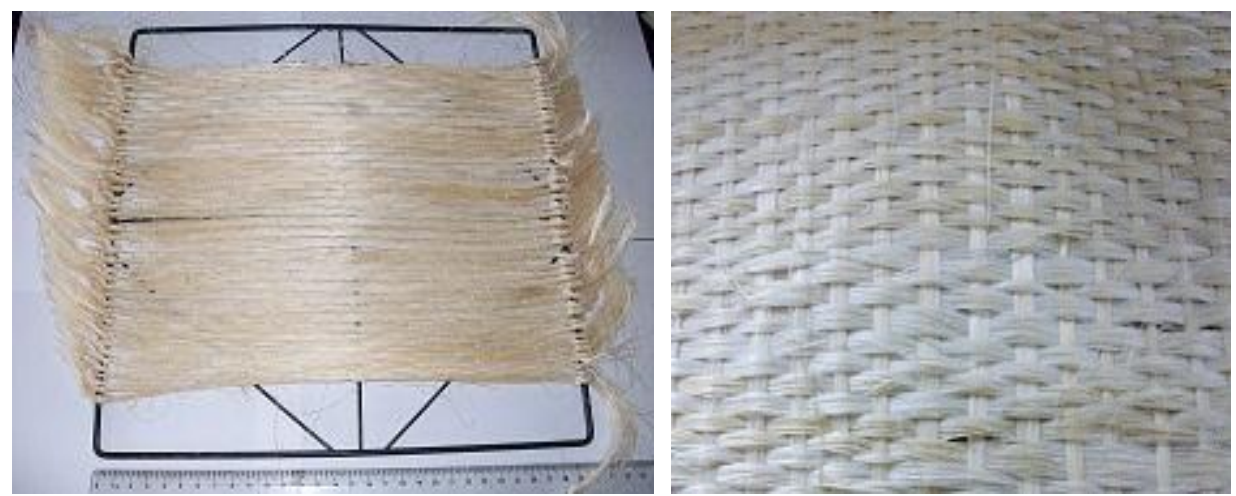

Figure 2. (a) Loom

(b) Tissue $2 \times 1$ of Basket Oxford type 


\section{Treatment}

Treatment in the tissue of sisal fibers was made with the fibers still disposed on the loom. The tissue was immersed in the solution of sodium hydroxide $(\mathrm{NaOH})$ to $3 \%$ for 1 hour, as shown in Fig. 3 , and after this procedure it was submitted to several baths of distilled water until reaching a neutral $\mathrm{pH}$.

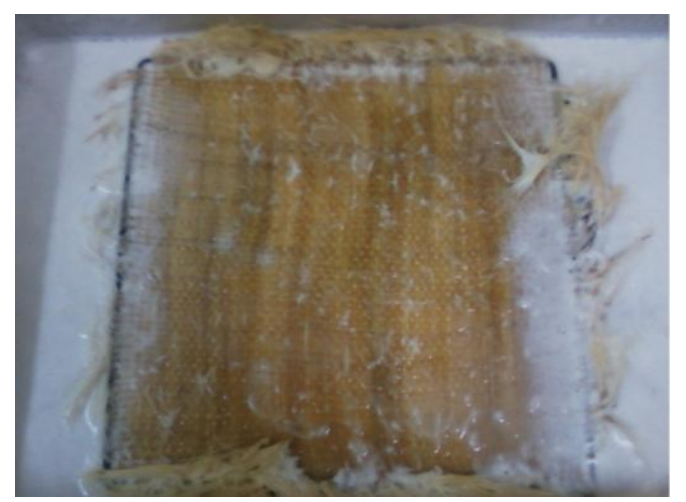

Figure 3. Alkaline treatment in the sisal fiber reinforcement.

\section{Manufacture of the composite}

Two types of composites were produced by hand lay- up process, as show fig.4, with $1 \%$ catalyst by volume referring to the polyester resin. One of the composites had as reinforcement the tissue of basket oxford type, and another included the same tissue but with the fibers treated with $\mathrm{NaOH}$ (mercerized composite), obtaining in this way, two plates. After curing, the specimens were cut for characterization of the composite and determination of its mechanical properties. All test specimens were cut with cutting blade of diamond wire.
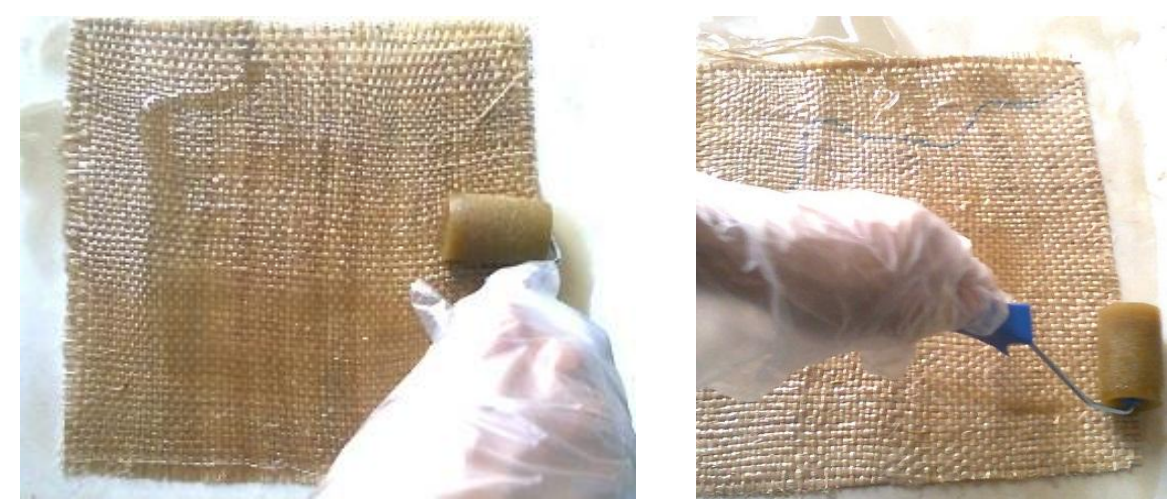

Figure 4. Lamination of the composite sisal/polyester. 


\section{Density test}

Density test the ASTM D792-00 standard was used for this test and from the average of five specimens the value of density of the composites was obtained.

\section{Bending test}

Bending test was performed according to ASTM D790-03. Ten test specimens were prepared with following dimensions: $12.7 \mathrm{~mm}$ wide, $45 \mathrm{~mm}$ in length and $2 \mathrm{~mm}$ thick. The tests were performed with a speed of $1 \mathrm{~mm} / \mathrm{min}$ and distance between supports of the $32 \mathrm{~mm}$. Standard was used for this test and, from the average of five specimens, the value of flexural properties of the composites was obtained.

\section{RESULTS AND DISCUSSION}

\section{Density test}

In Table 1, one can be observed that practically no variation occurred in the density of the composites manufactured with fibers treated and untreated chemically.

Table 1. Results of density test in the treated and untreated composites.

\begin{tabular}{|c|c|}
\hline Type of composite & Density $\left(\mathrm{g} / \mathrm{cm}^{\mathbf{3}}\right)$ \\
\hline Composite untreated & $0.99 \pm 0.01$ \\
\hline Composite treated (Mercerized) & $1.02 \pm 0.01$ \\
\hline
\end{tabular}

This increasing in density of treated composite occurred because of the elimination of lignin layer which was contained in the fibers, causing a rising of resin content and probably a drop of void content in the composite.

\section{Bending test}

The material that showed the best performance, with regard to the limit flexural strength, was the mercerized composite (subjected to chemical treatment), as shown in Figure 5. 


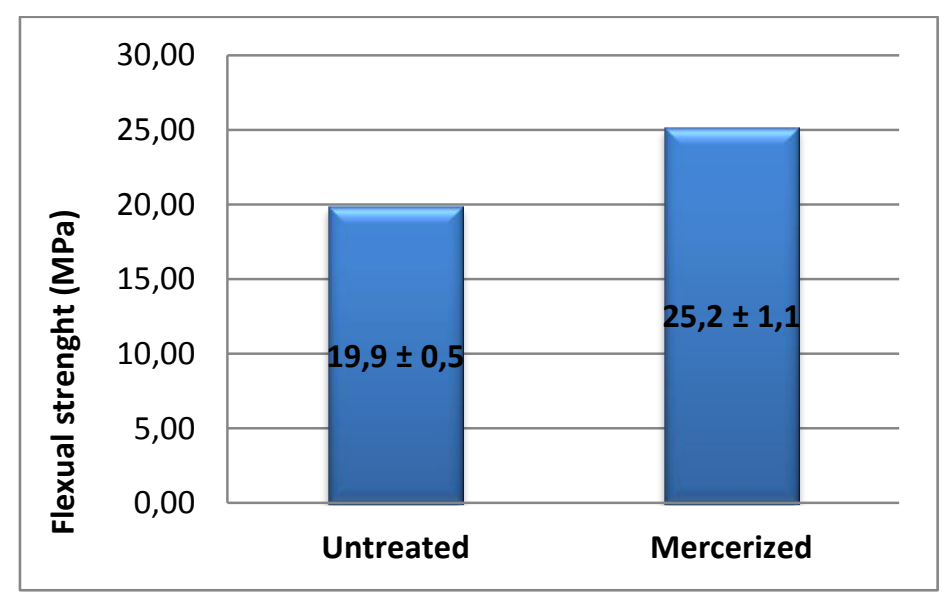

Figure 5. Flexural strenght of the treated and untreated composites.

It is possible observe a gain in the flexural strength of the composite at approximately $27 \%$ when the fiber was treated. Results were similar to those found by Sreekumar (2009), that by using a concentration of $5 \% \mathrm{NaOH}$ for fiber treatment, increased at $21 \%$ the flexural strength of the composite sisal / polyester. It is confirmed with literature which states when sodium hydroxide ( $\mathrm{NaOH}$ ) reacts with hydroxyl groups of the hemicellulose of the material, happens the destruction of cellular structure and thus the fibers are divided into strands, a phenomenon known as fibrillation, which breaks the bundles of treated fibers and decreases its diameter by the dissolution of hemicellulose and removal of lignin, which are cementing materials. Moreover, due to fibrillation, there is an increase of effective surface area available for contact with the matrix, as well as an increase in the percentage of crystallinity index of fibers due to the removal of cementing materials, which leads to a better packing of the chains cellulose, in most cases affecting positively the mechanical properties of fibers. This can be justified because of the defibrillation that occurs during treatment, thereby increasing the contact area between fiber and matrix (resin) interface, as stated by Cao (2006).

Analyzing the module of elasticity (flexural modulus) of the two composites studied here, one can observe that the untreated material had the best performance, as shown in Fig. 6 . 


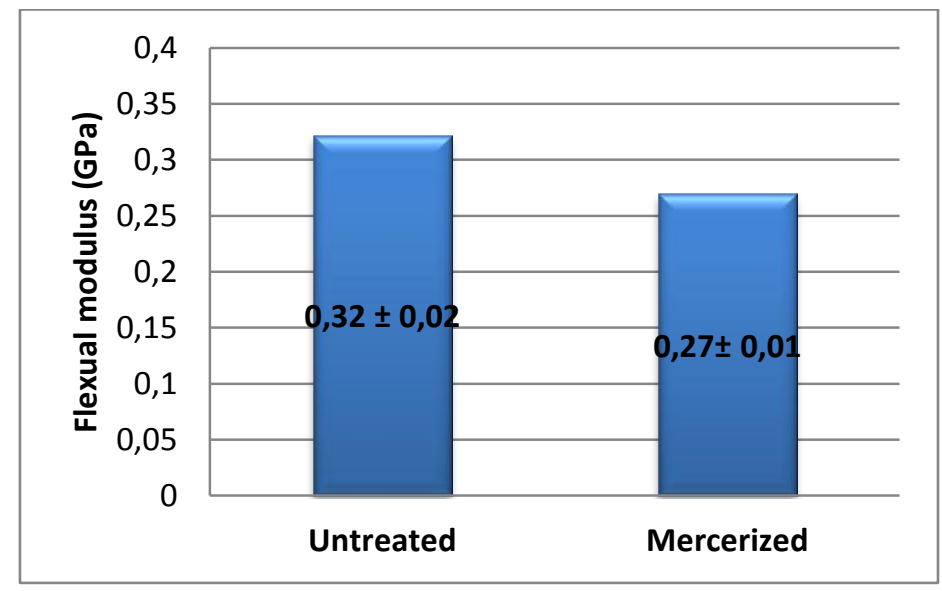

Figure 6. Flexural modulus of the treated and untreated composites.

The treated composite suffered a drop in stiffness at approximately $16 \%$, because the fiber became softer.

The maximum strain experienced by the composites can be observed in Fig. 7, showing once again that the composite chemically treated had the best performance reaching a larger deformation.

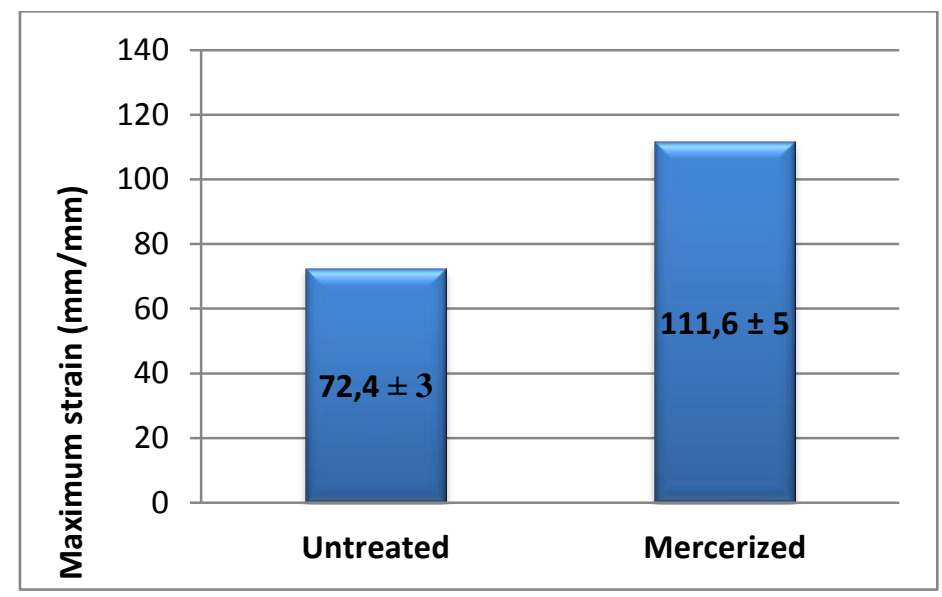

Figure 7. Maximum strain of the treated and untreated composites.

The strain of composite using treated tissue increase approximately $54 \%$. The results demonstrated the influence of chemical treatment on the mechanical behavior of the material. The $\mathrm{NaOH}$ decreases the waxy layer of the surface and increases the interaction of the reinforcement with the matrix, thus, the deformation of the composite increasing; similar results were obtained for Cao (2006). 


\section{CONCLUSIONS}

According to the results presented, one can observe that the material with better mechanical performance when subjected to three point bending test was the composite that had its reinforcement of sisal fibers treated with sodium hydroxide at $3 \%$, since it presented an increase of $27 \%$ and $54 \%$ in flexural strength and maximum strain, respectively, and a drop of approximately $16 \%$ in the modulus of elasticity when compared with the untreated composite.

\section{ACKNOWLEDGEMENTS}

To CNPq for research foment.

\section{REFERENCES}

1. ASTM D 790/03: Standard Test Methods for Flexural Properties of Unreinforced and Reinforced Plastics and Electrical Insulating Materials - American Society for Testing and, 1990.

2. ASTM D 792/00: Standard Test Methods for Specific Gravity and Density of Plastics by Displacement - American Society for Testing and Materials, 1979.

3. ANGRIZANI, C. A., VIEIRA, C. A. B., ZATTERA; A. J., FREIRE, E., SANTANA, R. M. C., AMICO, S. C. Influência do comprimento da fibra de sisal e do seu tratamento químico nas propriedades de compósitos com poliéster. In: 17ํㅡ Congresso Brasileiro de Engenharia e Ciência dos Materiais, Foz do Iguaçu-PR, Brasil. 2006.

4. AMICO, S. C., MOCHNACZ S., SYDENSTRICKER T. H. D. Tratamento melhora propriedades de fibras de sisal para uso em compósitos - Revista Plástico Industrial, São Paulo, Editora Aranda, Mar. 2004.

5. CAO, Y, SHIBATA, S, FUKUMOTO, I. Mechanical properties of biodegradable composites reinforced with bagasse fiber before and after alkali treatments. - Compos. Part A: Appl. Sci. Manuf. 37:423-9, 2006.

6. GAY, D. Matèriaux Composites. Paris: Editions Hermès, 1991.

7. JANG, B. Z. Interfaces and Interphases in Composites, Advanced Polymer Composites. ASM International, Materials Park, OH, 1994.

8. JOSEPHA, P. V., KURUVILLA, J., SABU, T. Effect of processing variables on the mechanical properties of Sisal-fiber-reinforced polypropylene composites. Elsevier Science Ltda., January 1999, Vol. 59: pp. 1625-1640.

9. LEVY, F. N. AND PARDINI, L. C. Compósitos Estruturais: Ciência e Tecnologia. 1. ed. São Paulo: Editora Edgard Blucher, 2006. 
10. MOCHNACZ, S., AMICO, S. C., SYDENSTRICKER, T. H. D. Caracterização e modificação Superficial de Fibras de Sisal Para Utilização em Compósitos Poliméricos.- Congresso em Ciências de Materiais do Mercosul, Joinville-SC, Brasil. 2002.

11. RONG, M. Z., ZHANG, M. Q., LIU, Y., YANG, G. C., ZENG, H.M. The effect of fiber treatment on the mechanical properties of unidirectional sisal-reinforced epoxy composites. - Elsevier Science Ltda., March 2001, Vol. 61: pp 1437-1447.

12. SILVA, R., HARAGUCHI, K. S., MUNIZ, C. E. E RUBIRA, A. F. Aplicações de fibras lignocelulósicas na química de polímeros e em compósitos - Quim. Nova, Vol. 32, No. 3, pp 661-671, 2009.

13. SREEKALA, M. S., THOMAS, S. Effect of fibre surface modification on water-sorption characteristics of oil palm fibres. - Elsevier Science Ltda., Vol. 63: pp 681-689, 2003.

14. SREEKUMAR, P. A., THOMAS, S. P., SAITER, J. M., KURUVILLA, J., UNNIKRISHNAN, G., SABU, T. Effect of fiber surface modification on the mechanical and water absorption characteristics of sisal/polyester composites fabricated by resin transfer molding. - Elsevier Science Ltda., August 2009, Vol. 40: pp 1777-1784.

15. SYDENSTRICKER, T. H. D., MOCHNAZ, S., AMICO, S. C. Pull-out and other evaluations in sisalreinforced polyester biocomposites. - Elsevier Science Ltda., Vol. 22: pp 375-380, 2003. 